\title{
The Oromo National Movement And Gross Human Rights Violations In The Age Of Globalization
}

\author{
Asafa Jalata \\ Professor of Sociology and Global and Africana Studies \\ Department of Sociology, University of Tennessee, Knoxville, USA
}

doi: 10.19044/esj.2016.v12n5p177 URL:http://dx.doi.org/10.19044/esj.2016.v12n5p177

\begin{abstract}
Today, the Oromo are an impoverished and powerless numerical majority and political minority ${ }^{13}$ in the Ethiopian empire; they have been the colonial subjects of Ethiopia, former Abyssinia, since the last decades of the 19th century. As the Ethiopian state colonized the Oromo with the help European imperialism, it has continued to terrorize, dominate, and exploit them with the help of successive global hegemonic powers such as England, the former Soviet Union, and the United States, To change the deplorable condition of the Oromo people, the Oromo movement is engaging in national struggle to restore the Oromo democratic tradition known as the gadaa system and to liberate the Oromo people from colonialism and all forms of oppression and exploitation by achieving their national self-determination. A few elements of Oromo elites who clearly understood the impact of Ethiopian colonialism and global imperialism on the Oromo society had facilitated the emergence of the Oromo national movement in the 1960s and 1970 s by initiating the development of national Oromummaa (Oromo national culture, identity, and nationalism). This paper focuses on and explores three major issues: First, it briefly provides analytical and theoretical insights. Second, the paper explains the past and current status of the Oromo people in relation to gross Oromo human rights violations. Third, it identifies and examines some major constraints and opportunities for the Oromo national movement and the promotion of human rights, social justice, and democracy.
\end{abstract}

\footnotetext{
${ }^{13}$ Numerically speaking, the Oromo are estimated between 40 and 50 million of more than 80 million people in the Ethiopian Empire alone, and they are larger than the combined size of Tigrayans and Amharas who have dominated and controlled the Ethiopian colonial state successively for more than a century. But, according to the Central Statistical Agency of Ethiopia, the Oromo population was about 27, Amhara 20, and the Tigrayan 4 million in 2007. Despite the fact that there are disagreements on the size of the Oromo population because of political reasons, it is an undisputable fact that the Oromo are the largest ethnonation in the empire. Some branches of the Oromo also live in Kenya and Somalia.
} 
Keywords: The Oromo national movement and gross human rights violations; national self-determination and democracy; colonialism and terrorism; Oromummaa and Oromo nationalism; globalization and social justice

Despite the fact that the Oromo resistance to Ethiopian colonialism started with the processes of colonization and subjugation, organized efforts by Oromo nationalists to liberate the Oromo people started in the 1960s. The emergence of the Macha-Tulama Self-Help Association (MTSA) in the early 1960s and the birth of the Oromo Liberation Front (OLF) in the early 1970s marked the development of Oromo nationalism or national Oromummaa and its national organizational structures. Currently, the Oromo people and their national struggle are at a crossroads because of four interrelated reasons: First, to suppress the Oromo people's struggle for national self-determination and multinational democracy, the Tigrayan-led Ethiopian government with the help of global powers is systematically and clandestinely attacking, killing or imprisoning, torturing, and terrorizing Oromo nationalists and other Oromos. Second, the Oromo are suffering from absolute poverty characterized by recurrent famines, diseases, and malnutrition because the Tigrayan state elites and transnational capitalists are looting their economic resources. Third, at the same time, the Oromo elites who suppose to provide guidance and leadership for the Oromo national movement are fragmented and have failed to understand the lethal danger the Oromo people are facing from the alliance of Tigarayan colonialism and global imperialism. Finally, the necessity of understanding the complexity of the Oromo national movement in order to take immediate tasks for consolidating the Oromo national struggle. Before I engage in my main discussion, let me briefly introduce my analytical and theoretical frameworks.

\section{Analytical and Theoretical Insights}

By drawing from an analytical framework that emerges from theories of the world system, globalization, nationalism, and social/national movements, this paper frames the Oromo national struggle in the global context. This work combines a structural approach to global social change with a social constructionist model of human agency of social/national movements. Hence, the Oromo national struggle is considered as an integral part of the global political project that has been attempting to humanize and democratize the racialized capitalist world system from below by establishing a single standard for humanity through eliminating all forms of exploitation and dispossession of economic resources and rights. Through examining the dynamic interplay of sociopolitical structures and human 
agencies that have facilitated the development of the Oromo national movement, this work employs interdisciplinary, multidimensional, historical, and critical approaches. The struggle for social emancipation, national selfdetermination, democracy, and popular sovereignty emerged in opposition to political absolutism, colonialism, racism, continued subjugation, and dispossession in the capitalist world system.

The critical understanding of the essence of global capitalism and its political structures and injustices are necessary to clearly recognize the principles for which the national struggle of the Oromo has developed. The Oromo have been denied basic aspects of their humanity since they were forced to enter into the global capitalist world system via slavery and colonialism that were facilitated by the alliance of Abyssinian/Ethiopian dependent colonialism and global imperialism (Holcomb and Ibssa 1990; Jalata 2005 [1993]). The capitalist colonial powers and their regional or local collaborators used superior military forces to enslave and colonize directly or indirectly pre-capitalist societies to exploit their labor power and/or to dispossess their economic resources through coercion, terrorism, looting, piracy, genocide, annexation, and continued subjugation (Jalata 2011). Consequently, the original accumulation of wealth and capital occurred; this capital accumulation gradually facilitated the transformation of mercantilism into industrial capitalism and the development and expansion of the Industrial revolution in the West in the $18^{\text {th }}$ and $19^{\text {th }}$ centuries and increased the demand for more raw materials, free or cheap labor (mainly slaves), markets, and the intensification of global colonial expansion (Marx 1967; Rodney 1972).

The development of global capitalism, the accumulation and concentration of capital or economic resources through the separation of the actual producers from their means of production, such as land, led to the racialization/ethnicization and socialization of labor. As Karl Marx (1967: 17) notes, "The expropriation of the agricultural producers, of the peasant, from the soil, is the basis of the whole process. The history of expropriation, in different countries, assumes different aspects, and runs through its various phases in different orders of succession, and different periods." The processes of expropriation, racial slavery, and colonialism resulted in hierarchical organization of world populations through the creation of an elaborate discourse of race or racism. As the meaning of race is illusive and complex, so is that of racism. Racism can be defined as a discourse and a practice in which a racial/ethnonational project is politically, socially, culturally, and 'scientifically' constructed by elites in the capitalist world system to naturalize and justify racial/ethnonational inequality in which those at the top of the hierarchy oppress and exploit those below them by claiming biological and/or cultural superiority. "A racial project is 
simultaneously an interpretation, representation or explanation of racial dynamics," Howard Winant (1994: 24) writes, 'and an effort to organize and distribute resources along particular racial lines” (author's emphasis). Simply put, racism is an expression of institutionalized patterns of colonizing structural power and social control in order to transfer labor and economic resources from the powerless to the powerful group.

By inventing nonexistent races, the racist ideology institutionalizes "the hierarchies involved in the worldwide division of labor" (Balibar \& Wallerstein 1991: 6). Race and racism are socio-political constructs since all human groups are biologically and genetically more alike than different (Malik 1996). To justify racial slavery and colonialism, colonial terrorism, genocide, the ideology of racism was developed in scientific and religious clothing and matured during the last decades of the $19^{\text {th }}$ and the beginning of the $20^{\text {th }}$ centuries. ${ }^{14}$ Since the 1970 s, with the intensification of the crisis of the process of capital accumulation and the declining of the US hegemony in the capitalist world system, the West under the leadership of the US has started to promote a policy known as neoliberalism to revitalize global capital accumulation (Harvey 2005). As David Harvey (2005: 7) demonstrates, through the policy of neoliberalism the neo-liberal state has intensified the process of capital accumulation by dispossession of economic resources and rights; the "fundamental mission [of the neo-liberal stat] was to facilitate conditions for profitable capital accumulation on the part of both domestic and foreign capital." Accumulation of capital by dispossession involves state terrorism and genocide as the case of the Oromo illustrates (Jalata 2011).

Bruce Hoffman (2006: 40) "defines terrorism as the deliberate creation and exploitation of fear through violence or the threat of violence in the pursuit of political change.... Terrorism is specifically designed to have farreaching psychological effects beyond the immediate victim(s) or object of the terrorist attack." Although the struggle of the Oromo and other peoples forced the Ethiopian colonial state to "nationalize" the land and make it "collective property" between 1975 and 1991, the United States supported the emergence of the Tigryan-led Ethiopian government that has intensified state terrorism, genocide, and capital accumulation by dispossessing the land of Oromo farmers and that of other ethnonational groups in the Ethiopian Empire (Jalata 2005). Both the Ethiopian colonial state and the big powers of the capitalist world system as well as China have allied in maintaining

14 Hannah Arendt explored the dynamic relationships among capitalist imperialism, colonialism, racism, fascism, and genocide (King and Stone 2007). According to Tony Barta (2007: 100), “Arendt brought us closer to historical understanding of the murderous progress of modernity, by relating-brilliantly but too briefly-genocide in the colonies to developments far away." 
capitalism through intensifying capital accumulation by any means necessary. "The process of integration of neocolonial states into the global economy, seeking the protection of the imperial state," Berch Berberoglu (2003: 108) writes, “ has been to a large degree a reaction to a perceived threat to the survival of capitalism in the Third World — one that is becoming a grave concern for both imperialism and the local repressive capitalist states."

Although the struggle of the impoverished peoples like that of the Oromo cannot threaten global imperialism, powerful countries like the United States have sided with the Tigrayan-led minority regime of Ethiopia because of their racist and modernist political and economic models (Wolfe 1998) that ignore the principles of social justice, fairness, democracy, and national self-determination. As the Oromo national movement has continued to resist the criminal policies of the Ethiopian government, the regime has increased its terrorist activities and dispossession of lands and other resources with the support of Western powers, emerging powers of China, India, and some Arab countries, as well as international institutions, such as the World Bank and the International Monetary Fund. ${ }^{15}$ With the support of powerful countries, terrorist regimes in Third World countries have used various forms of terror such as rape, physical and psychological torture, violent arrest, secret or open imprisonment and usually death, disappearances (euphemism for secret killings), assassinations, castration, etc. We should "regard life and liberty as something like absolute values and then try to understand the moral and political processes through which these values are challenged and defended" (Waltzer xvi). Since the international system, particularly the United Nations, lacks a single standard for humanity in a practical sense, some states get away with the crimes they commit against their own citizens and other peoples (Jalata 2011). The lack of demanding responsibility from certain states such as that of Ethiopia in the international system leaves a room for engaging in state terrorism and committing genocide.

\footnotetext{
${ }^{15}$ Edward S. Herman (1982: 3) recognizes the central roles of these entities in Third World counties like Ethiopia, and notes the following: "There is huge tacit conspiracy between the U.S. government, its agencies and its multinational corporations, on the one hand, and local business and military cliques in the Third World, on the other, to assume complete control of these countries and 'develop' them on a joint venture basis. The U.S. security establishment to serve as the 'enforcers' of this joint venture partnership carefully nurtured the military leaders of the Third World, and they have been duly supplied with machine guns and the latest data on methods of interrogation of subversives.... The 'side effects' in the form of widespread hunger, malnutrition, diseases, poverty and social neglect, millions of stunted children, and a huge reserve army of structurally unemployed and uncared for people are the regrettable but necessary costs of 'growth' and 'development.' These side effects have not been heavily featured in the Western media."
} 
Despite the fact that the United Nations has theoretically recognized the problems of state terrorism and genocide, it did not yet develop effective policies and mechanisms of preventing them because powerful countries and their client states that commit such crimes against humanity have dominated the United Nations. Article II of the United Nations Convention defines genocide as "acts committed with intent to destroy, in whole or in part, a national, ethnical, racial or religious group.” Kurt Jonassohn (1998: 9) also defines genocide as the planned destruction of any economic, political or social group.” According to Frank Chalk and Kurt Jonassohn (1990: 23), "GENOCIDE is a form of one-sided mass killing in which a state or other authority intends to destroy a group, as that and membership in it are defined by the perpetrator." Chalk and Jonassohn (1990: 23) identify two major types of genocide: the first type is used to colonize and maintain an empire by terrorizing the people perceived to be real or potential enemies. In this case, the main purpose of practicing genocide is to acquire land and other valuable resources. Then the maintenance of colonial domination by state elites requires the establishment of a cultural and ideological hegemony that can be practiced through repression and genocidal massacres. By destroying elements of a population that resists colonial domination, hegemony can be established on the surviving population. This is the second type of genocide; this form of genocide is called ideological genocide. Jonassohn (1998: 23) notes that ideological genocide develops "in nation-states where ethnonational groups develop chauvinistic [and racist] ideas about their superiority and exclusiveness." As it can be demonstrated below, since their incorporation into the racialized capitalist world system through the dependent colonialism of Abyssinia/Ethiopia, the Oromo have been facing state terrorism, genocidal massacres, and dispossession of economic and cultural resources that they have been fighting against in various forms.

\section{The Past and Current Status of the Oromo People}

The Ethiopian colonial terrorism and genocide that started during the last decades of the 19th century still continue in the 21st century. The Abyssinian/Ethiopian or Amhara and Tigrayan warlords terrorized and committed genocide on the Oromo people during the Scramble for Africa with the help of European imperial powers such as Britain, France, and Italy, and the modern weapons they received from them (Holcomb 1990; Jalata 2005 [1993]). During Ethiopian (Amhara-Tigray) colonial expansion, Oromia, "the charming Oromo land, [would] be ploughed by the iron and the fire; flooded with blood and the orgy of pillage” (de Salviac 2005 [1901]: 349). Calling this event as "the theatre of a great massacre," Martial de Salviac (2005:349) states,

The conduct of Abyssinian armies invading a land is simply barbaric. 
They contrive a sudden irruption, more often at night. At daybreak, the fire begins; surprised men in the huts or in the fields are three quarter massacred and horribly mutilated; the women and the children and many men are reduced to captivity; the soldiers lead the frightened herds toward the camp, take away the grain and the flour which they load on the shoulders of their prisoners spurred on by blows of the whip, destroy the harvest, then, glutted with booty and intoxicated with blood, go to walk a bit further from the devastation. That is what they call 'civilizing a land.'

The Oromo oral story also testifies that the Abyssinian armies looted the resources of Oromia (the Oromo country), and committed genocide on the Oromo people through terrorism, massacre, slavery, depopulation, cutting hands or breasts, series of famines, and diseases during and after the colonization. Recognizing this tragedy, "the Oromo said: 'It is Waaqa [God] . . . who has subjected us to the Amhara' [and Tigray]" (de Salviac 2005: 350). According to Martial de Salviac (2005: 8), "With equal arms, the Abyssinia [would] never [conquer] an inch of land. With the power of firearms imported from Europe, Menelik [Abyssinian warlord] began a murderous revenge.”

The colonization of Oromia involved human tragedy and destruction: "The Abyssinian, in bloody raids, operated by surprise, mowed down without pity, in the country of the Oromo population, a mournful harvest of slaves for which the Muslims were thirsty and whom they bought at very high price. An Oromo child [boy] would cost up to 800 francs in Cairo; an Oromo girl would well be worth two thousand francs in Constantinople" (de Salvic 2005: 28). The Abyssinian/Ethiopian government massacred half of the Oromo population (five million out of ten million) and their leadership during its colonial expansion (Bulatovich 2000: 68). According to Alexander Bulatovich (2000: 68-69), "The dreadful annihilation of more than half of the population during the conquest took away from the [Oromo] all possibilities of thinking about any sort of uprising ... Without a doubt, the [Oromo], with their least five million population, occupying the best land, all speaking one language, could represent a tremendous force if united.” The destruction of Oromo lives, institutions, and Oromian natural beauty were aspects of Ethiopian colonial terrorism. The surviving Oromo who used to enjoy an egalitarian democracy known as the gadaa system ((Legesse 1973, 2006) were forced to face state terrorism, genocide, political repression, and an impoverished life. Bulatovich (2000: 68) explains about the gadaa administration as follows: "the peaceful free way of life, which could have become the ideal for philosophers and writers of the eighteenth century, if they had known it, was completely changed. Their peaceful way of life is broken; freedom is lost; and the independent, freedom loving [Oromo] find 
themselves under the severe authority of the Abyssinian conquerors.”

The Ethiopian colonialists also destroyed Oromo natural resources and the beauty of Oromia. Oromia was "an oasis luxuriant with large trees” and known for its "opulent and dark greenery used to shoot up from the soil” (de Salviac 2005: 21-22). De Salviac (2005: 20-21) also notes, "the greenery and the shade delight the eyes all over and give the landscape richness and a variety which make it like a garden without boundary. Healthful climate, uniform and temperate, fertility of the soil, beauty of the inhabitants, the security in which their houses seem to be situated, makes one dream of remaining in such a beautiful country." The Abyssinian colonialists devastated "the forests by pulling from it the laths for their houses and [made] campfires or firewood for their dwellings.... [T] of trees, others [accused] them of exercising their barbarity against the forests for the sole pleasure of ravaging” (de Salviac 2005: 20). Bulatovich (2000: 21) applied to Oromia the phrase "flowing in milk and honey" to indicate its abundance of wealth in cattle and honey. The Ethiopian colonial state gradually established settler colonialism in Oromia and developed five major types of colonial institutions, namely, slavery, the colonial landholding system, the nafxanya-gabbar system (semi-slavery), the Oromo collaborator class, and garrison and non-garrison cities (Jalata 2005). It introduced the process of forced recruitment of labor via slavery and the nafxanya-gabbar (semi-slavery) system (Holcomb and Ibssa 1990: 135). The colonial state expropriated almost all Oromo lands and divided up the Oromo among colonial officials and soldiers and their collaborators to force them to produce agricultural commodities and food for local consumption and an international market.

The Oromo farmers were reduced to serfs or slaves or semi-slaves and coerced to work without remuneration for the settlers, intermediaries, and the colonial state for certain days every week. Whenever they failed to provide free labor or pay taxes or tributes, the settlers enslaved their children or wives (Jalata 2005; Holcomb and Ibssa 1990). The colonial policies that started during the reign of Menelik have continued under successive Ethiopian governments. The Haile Selassie government continued the policies of Menelik until it was overthrown by the popular revolt of 1974 . The Selassie government terrorized the Oromo of Raya-Azabo, Wallo, Hararghe, Bale and other regions because of their political and cultural resistance to the Amhara-Tigray colonial domination. It also imprisoned, tortured or hanged prominent Oromo leaders such as Mamo Mazamir and Haile Mariam Gamada who organized and led the Macha-Tulama Self-Help Association in the 1960s. The military regime that emerged in 1974 under the leadership Colonel Mengistu Haile Mariam continued state terrorism, dictatorship, and the subjugation of the Oromo. When Oromo activists and 
the people started to resist the military regime, it intensified its state terrorism and genocide.

The Military regime known as also the derg had committed massive human rights violations in the 1970s and 1980s in the name of the so-called Revolution and "socialism" with the assistance of the so-called socialist countries such as the former Soviet Union and its satellite countries. ${ }^{16}$ In the 1980s, thousands of Oromo nationalists were murdered or imprisoned; the regime also terrorized other elements of Oromo society. According to Gunnar Hasselblatt (1992: 17-19), the military government

repeatedly held mass shooting among the Oromo population, hoping to break the free, independent Oromo spirit. Sometimes a hundred, sometimes two hundred men were shot on this raised dry field . . . and were buried with bulldozers. Over years this procedure was repeated several times. When the method did not work and the Oromo population could not be forced into submission, other methods were used. The victims were made to lie down with their heads on stone, and their skulls were smashed with another stone. The . . . government . . . tried everything to consolidate its reign of terror and exploitation of Oromia . . . When the Oromo movement could not be quenched by shooting or by the smashing of skulls, [the government] came up with a new idea. Men's testicles were smashed between a hammer and an anvil. Three men tortured and maimed in this way are still living.

Ethiopia has maintained its oppressive and repressive structures on the Oromo by the assistance of successive global powers, namely, Great Britain, the United States, former Soviet Union, as well as China (Jalata 2012). Replacing Great Britain, the United States supported the Haile Selassie government between the 1950s and the early 1970s, when the former Soviet Union started to assist the new military regime that claimed to promote socialism. As the former Soviet Union supported the Mengistu regime, the US, powerful European countries and China are supporting the Tigrayan-led Ethiopian government. Currently, the Tigrayan-led regime is continuing similar colonial policies and practices in Oromia and other places. The only

\footnotetext{
${ }^{16}$ According to Norman J. Singer (1978: 672-673), “Those killed in the first three months of the campaign of the 'Red Revolutionary Terror' . . . numbered around 4000-5000 [in Finfinnee (Addis Ababa) alone], the killings continued in March 1978, spreading to the rest of the country . . . Those detained for political instruction numbered from 30,000 upwards . . . Torture methods emphasized in the Red Terror . . . included severe beating on the head, soles of the feet . . . and shoulders, with the victim hung by the wrists or suspended by wrists and feet from a horizontal bar . . . ; sexual torture of boys and girls, including pushing bottles or red-hot iron bars into girls' vaginas and other cruel methods.” In 1980, one Oromo source said, "the Oromo constitutes the majority of the more than two million prisoners that glut Ethiopia's jails today" (The Oromo Relief Association 1980: 30).
} 
difference now is that the Tigrayan state elites are the ones that dominate and lead the Ethiopian colonial state instead of the Amhara colonialists that led the Ethiopian state from the last decades of the $19^{\text {th }}$ century until 1991.

Since 1992, the Tigrayan authoritarian-terrorist regime (Jalata 2010) has controlled the Oromo and denied them the freedom of expression, association, organization, the media, and all forms of communication and information networks. This government has been focusing on brutally attacking the Oromo national movement led by the Oromo Liberation Front (OLF) and on robbing the economic resources of Oromia in order to enrich the Tigrayan elites and their collaborators and to specifically develop the Tigrayan region. To achieve its political and economic objectives, the regime primarily uses its puppet organization known as the Oromo People's Democratic Organization (OPDO), which was created and is controlled by the Tigrayan People's Liberation Front (TPLF); the OPDO is staffed by Tigrayan cadres, elements of Oromo speaking colonial settlers, and opportunistic Oromos who would do anything in exchange for luxurious lifestyles. The minority Tigrayan-led Ethiopian government is attempting to give a final solution for a large political problem that has existed for several centuries - the relationship between the Oromo and their Amhara-Tigrayan colonizers. As we know from history, the policy of targeting and exterminating indigenous peoples has existed in different parts of the world, and it has been an integral practice of the racialized capitalist world system since the 16th century. ${ }^{17}$ This regime is now completing the forced removal of Oromos from the areas surrounding Finfinnee (Addis Ababa) (Worku 2008: 97-131).

The Tigrayan regime tried to implement the so-called Addis Ababa Master Plan that the Oromo called "the Master Genocide” in 2014, and the Oromo in general and the Oromo students in particular peacefully resisted this genocidal policy that was intended to totally uproot Oromo farmers around the capital city and transfer their lands to Tigrayans and supporters. The regime killed or imprisoned Oromo students and others who opposed the so-called the Addis Ababa Master Plan. Almost all Oromo students have opposed this plan and peacefully demonstrated all over Oromia. Furthermore, by evicting the Oromo farmers from their homelands with

\footnotetext{
${ }^{17}$ While claiming to promote Christian civilization, modernity, and commerce, European colonialists exterminated indigenous peoples in the Americas, Australia, Asia, and Africa over a period of several centuries in order to transfer their resources to European colonial settlers and their descendants. Specifically, the plans and actions that King Leopold of Belgium had for the Congo or Andrew Jackson of the United States for the Cherokees or colonial Germany for the Herero and Nama peoples in South West Africa (Nambia) (Hochschild 1998; Kiernan 2007; Sturgis 2007; Herbert 2003) are very similar to the grand plan and action the Tigrayan-led Ethiopian government has for the Oromo nation.
} 
nominal or without compensation, the regime has already leased several millions hectares of Oromo lands to so-called investors from Ethiopia, China, Djibouti, Saudi Arabia, India, Malaysia, Nigeria, UK, Israel, as well as from Europe (Rahmato 2011; Giorgis 2009). The local and transnational capitalists have intensified the process of capital accumulation by dispossession of the Oromo and others under the leadership of the Tigraynled Ethiopian government. If the policy of land grabbing is allowed to continue, Tigrayans, Amharas, Chinese, Djiboutians, Indians, Malaysians, Nigerians, Arabs, English, Jews, Asians, Europeans and others will soon replace the Oromo people in Oromia and beyond.

The Tigrayan state elites have never sold or leased Tigrayan lands, but have expanded modern agricultural development in their homeland, Tigray. Tamrat G. Giorgis (2009: 1), Addis Fortune staff writer, explains as follows: "A new global trend is rising whereby companies from emerging economies grab vast land in poor host nations to grow and export cereals and grains to their home countries. It has happened here in Bako [Oromia,], where people from India have been granted tens of thousands of hectares of land for commercial farming. The locals, however, are unhappy." The Tigrayan regime also sells Oromo minerals and other natural resources while evicting and impoverishing the Oromo people. Whenever the Oromo resist, the regime mercilessly brutalizes or kills them. In this era of globalization, the Tigrayan regime is advised, financed, and legitimized by the transnational capitalist class. Global powers such as the US, the European Union, and countries of emerging economies have collaborated with the Tigrayan-led regime to suppress the OLF in order to expropriate the economic resources of the Oromo people. ${ }^{18}$ Millions of Oromos who have lost their economic resources and those who are targeted for their political views have immigrated to the Middle East, Australia, Europe, and North America and to different countries in Africa. They have been mistreated in some African countries and the Middle East, and they have been denied the right to be refugees. The majority of the Oromo who live under the control of the Tigrayan-led regime are facing serious social and political problems in their

\footnotetext{
${ }^{18}$ In this process, some Oromos have been uprooted from their communal ancestral lands, alienated, and impoverished. As William I. Robinson (2008: 23) notes, "There is . . . the rise of a new global "underclass" of supernumeraries or "redundants" who are alienated and not absorbed into the global capitalist class economy and who are structurally under- and unemployed. Hundreds of millions of supernumeraries swell the ranks of a global army of reserve labor at the same time as they hold down the wages and leverage ability among those absorbed into the global economy. The supernumeraries are subject to new forms of repressive and authoritarian social control and to an oppressive cultural and ideological dehumanization.... This culture of global capitalism glorifies policing and militarization, constructs all those who resist, or even question the logic of the dominant order as incomprehensible, even crazed, Other.”
} 
own country.

The US, the European Union, and China have built and consolidated the Tigrayan-led Ethiopian regime to perform the following important services: "(1) adopt fiscal and monetary policies that ensure macroeconomic stability; (2) provide the basic infrastructure necessary for global economic activity (airports and seaports, communication networks, educational systems, etc.); and (3) provide social order, that is, stability, which requires sustaining instruments of social control, coercive and ideological apparatus" (Robinson 2008: 33). The Tigrayan-led regime is an organ of capital accumulation for Tigrayan and transnational elites, and it uses terrorism and massive human rights violations to separate the indigenous communities such as the Oromo and others from their lands and other resources (Jalata 2005). Furthermore, the World Bank, IMF, UN, EU, African Union, and most NGOs as structures of global capitalism are the facilitators of regional and global capital accumulators, and they are not interested in promoting human rights and democracy in peripheral countries like Ethiopia (Jalata 2005). The political and military leaders of the Ethiopian government are literally gangsters and robbers; they use state power to expropriate lands and other resources in the name of privatization-all with the blessing of the World Bank and the International Monetary Fund. In achieving its political and economic objectives, the regime has been engaging in political repression, state terrorism, genocidal massacres, and gross human rights violations in Oromia and other regional states.

Since the Oromo people have been resisting to Tigrayan colonial policies, they have been targeted by the regime; they have been attacked and terrorized because of their economic resources, their acceptance of the OLF as their national leadership, and their refusal to submit to the orders of Tigrayan authorities and their collaborators. The Ethiopian regime has also banned independent Oromo organizations including the OLF and declared war on those organizations and the Oromo people. It even outlawed Oromo journalists and other writers and closed down Oromo newspapers. As Mohammed Hassen (2002: 31) asserts, "The attack on the free press has literally killed the few publications in the Oromo language in the Latin alphabet. The death of Oromo publications . . . has been a fatal blow to the flowering of Oromo literature and the standardization of the Oromo language itself. The Oromo magazines that have disappeared include Gada, Biftu, Madda Walaabuu, Odaa, and the Urjii magazine . . . Since 2002, there has not been a single newspaper or magazine that has expressed the legitimate political opinions of the Oromo in Ethiopia.” Almost all Oromo journalists are either in prison or killed, or in exile. The regime also banned Oromo musical groups and all professional associations. Expanding their political repression, government authorities formed quasi-government institutions 
known as gott and garee to maintain tighter political control over Oromia; they "imposed these new structures on . . . [rural] communities . . . More disturbing, regional authorities are using the gott and garee to monitor the speech and personal lives of the rural population, to restrict and control the movements of residents, and to enforce farmers' attendance at 'meetings' that are thinly disguised OPDO political rallies” (Human Rights Watch 2005: 2).

Generally speaking, the Ethiopian government has continued to eliminate or imprison politically conscious and self-respecting Oromos. Today, thousands of Oromos are in official and secret prisons or concentration camps simply because of their nationality and their resistance to injustice. After jailed and released from prison after six years, Seye Abraha (2008), the former Defense Minister of the regime who had previously participated in the massacring and imprisoning thousands of Oromos, testified on January 5, 2008, to his audience in the state of Virginia in the U. S. that "esir betu Oromigna yinager," ("the prison speaks Oromiffa [the Oromo language]" and also noted that "about 99\% of the prisoners in Qaliti are Oromos.” The Tigrayan state bureaucrats believe that Oromo intellectuals, businessmen and women, conscious Oromo farmers, students, and community and religious leaders are their enemies, and, hence, should be destroyed through political repression and state terrorism (Hizbawi Adera 1996-1997). State terrorism is their main tool in repressing and destroying Oromo nationalists. State terrorism is associated with issues of control over territory and resources and the construction of political and ideological domination (Oliverio 2007). It has manifested itself as lethal violence in the form of war, assassination, murder, castration, burying alive, throwing off cliffs, hanging, torture, rape, poisoning, forcing people to submission by intimidation, beating, and disarmament of citizens (Pollock 1997; Trevor 2007).

The methods of killings have also included burning, bombing, and the cutting of throats or arteries in the neck, strangulation, shooting, and the burying of people up to their necks in the ground. The agents and militia of the regime have burned houses and entire villages, exterminating millions of Oromo men, women, and children. The regime has also practiced different forms of torture on imprisoned Oromos and others; former prisoners have testified that their arms and legs were tied tightly together on their backs and their naked bodies were whipped; large containers or bottles filled with water were fixed to their testicles, or if they were women, bottles or poles were pushed into their vaginas (Trueman 2001; Survival International 1995). There were prisoners who were locked up in empty steel barrels and tormented with heat in the tropical sun during the day and with cold at night; there were also prisoners who were forced into pits so that fire could be made on top of them (Trueman 2001). The cadres, soldiers, and officials of 
the regime have frequently raped Oromo girls and women to demoralize them and their communities and to show how Tigrayan rulers and their collaborators wielded limitless power. As Bruna Fossati, Lydia Namarra and Peter Niggli (1996: 10) report, "in prison women are often humiliated and mistreated in the most brutal fashion. Torturers ram poles or bottles into their vaginas, connect electrodes to the lips of their vulva, or the victims are dragged into the forest and gang-raped by interrogation officers."

Ethiopian soldiers have collected young Oromo girls and women into concentration camps and gang raped them in front of their relatives, fathers, brothers, and husbands to humiliate them and the Oromo people. Statesanctioned rape is a form of terrorism. The use of sexual violence is also a tactic of genocide that a dominant ethnonational group practices in order to destroy a subordinate ethnonational group. What Catherine MacKinnon (1994: 11-12) says about ethnic cleansing in Croatia and BosniaHerzegovina applies to the sexual abuse of Oromo girls and women by the Tigrayan-led regime: "It is also rape unto death, rape as massacre, rape to kill and to make the victims wish they were dead. It is rape as an instrument of forced exile, rape to make you leave your home and never want to go back. It is rape to be seen and heard and watched and told to others: rape as spectacle. It is rape to drive a wedge through a community, to shatter a society, to destroy a people. It is rape as genocide.” The Tigrayan-led regime has used various mechanisms in repressing, controlling, and destroying the Oromo people. It has imprisoned or killed thousands of Oromo women and men. Its agents have murdered prominent community leaders and left their corpses for hyenas by denying them burial to impose terror on the Oromo people.

Furthermore, relatives of the murdered Oromos are not allowed to cry publicly to express their grievances, a once cultural practice. For example, the wife of Ahmed Mohamed Kuree, a seventy year-old elderly farmer, expressed on February 21, 2007, on the Voice of America, Afaan Oromo Program the following: "We found his prayer beads, his clothes and a single bone of his which the hyenas had left behind after devouring the rest of his body, and we took those items home. What is more, after we got home, they [government agents] condemned us for going to Gaara Suufii and for mourning. For fear of repercussions, we have not offered the customary prayer for my husband by reading from the Qur'an. Justice has not been served. That is where we are today.” Another Oromo, Ayisha Ali, a fourteen year-old teenager, was also killed and eaten by hyenas. Her mother said on the Voice of America, Afaan Oromoo Program, the following: "After we heard the rumor about the old man [Ahmed Mohamed Kuree] I followed his family to Gaara Suufii [in search of my daughter]. There we found her skirt, sweater, underwear and her hair, braided . . . That was all we found of my 
daughter's remains.” Ayisha was probably raped before she was killed. According to Human Rights Watch (2005: 1-2), "Since 1992, security forces have imprisoned thousands of Oromo on charges of plotting armed insurrection on behalf of the OLF. Such accusations have regularly been used as a transparent pretext to imprison individuals who publicly question government policies or actions. Security forces have tortured many detainees and subjected them to continuing harassment and abuse for years after their release. That harassment in turn has often destroyed victims' ability to earn a livelihood and isolated them from their communities.” The regime has even targeted Oromia's environment and its animals. According to Mohammed Hassen (2002: 37-38),

Oromo men, women, children, animals, and even the Oromo environment are all targets of the [Tigrayan] tyranny. In cases where Oromo pastoralists were suspected of harboring OLF guerrilla fighters, [Tigrayan] soldiers punished them by destroying or confiscating their cattle or by poisoning the wells from which the cattle drank. On many occasions Oromo farmers, suspected of feeding OLF fighters, saw their farms burned to the ground and the defenseless members of their households brutally murdered. In 2000, when the [Tigrayan] government suspected OLF guerrillas of hiding in the forests of Oromia, its agents set fires that caused catastrophic environmental destruction in Oromia and other states in southern Ethiopia.

In addition to such environmental destruction and the murdering and raping of Oromo girls and women, the regime has engaged in the genocidal massacres of Oromos. It has engaged in such crimes with little or no opposition from Western powers, particularly the United States. All these crimes against humanity are committed in the name of democracy, federalism, and development. The Tigrayan-led government sees Oromia as part of its empire, controls all of Oromia's resources, and attacks the Oromo since it perceives them as its potential or real enemies. It engages in genocide with the intention of destroying sectors of the Oromo nation composed of nationalists and leaders. Tigrayan state leaders are claiming to promote political ideologies such as "revolutionary democracy" and "federalism," while at gunpoint attempting to legitimize Tigrayan ethnocracy and state power.

These state elites deny that they engage in human rights violations by claiming that they are democrats and revolutionaries; they are destroying the records of their political crimes. Johnassohn's description of a conspiracy of "collective denial" of genocide is applicable to the denial of the occurrence of genocide in the Ethiopian Empire. According to Johnassohn (1981: 11), "There are many reasons for this: (a) in many societies such materials are not 
written down, or are destroyed rather than preserved in archives; (b) many perpetrators have recourse to elaborate means of hiding the truth, controlling access to information, and spreading carefully contrived disinformation; and (c) historically, most genocides were not reported because . . . there appears to have existed a sort of conspiracy of 'collective denial' whereby the disappearance of a people did not seem to require comment or even mention.” While the Tigrayan regime has been eliminating Oromo leaders through genocide in order to deny the Oromo their own political leadership, it has been preparing Tigrayan children for positions of leadership by providing them access to a better education. This regime also limits the educational opportunities of Oromo children to maintain racial/ethnic division of labor.

Although it is impossible to know exactly at this time how many Oromos have been murdered by the Tigrayan-led government, Mohammed Hassen (2001) estimates that between 1992 and 2001, about 50,000 killings and 16,000 disappearances (euphemism for secret killings) took place in Oromia; he also notes that 90 percent of the killings were not reported. The government hides its criminal activities and "does not keep written records of its extrajudicial executions and prolonged detention of political prisoners" (Hassen 2001: 30). Furthermore, the massive killings and genocide committed on the Sheko, Mezhenger, Sidama, Annuak, and Ogaden Somali peoples have shocked some sections of the international community. For instance, in 2002, when the Sheko and Mezhenger peoples demanded their rights, the regime killed between 128 and 1,000 people. Nobody knows exactly how many people were killed since the government and the victims gave different numbers. Similarly, on June 21, 2002, between 39 and 100 Sidamas were killed when government soldiers fired at 7,000 peaceful demonstrators in Hawasa. Again government forces and colonial settlers committed genocidal massacres on the Annuak people of Gambella in December 2003 and beginning 2004; they killed 424 people and displaced about 50, 000 people. The regime has engaged in genocidal massacres, imprisonment, and massive human rights violations in Ogadenia and Oromia. Because of these reasons Meles Zenawi and his followers were possible targets of the International Criminal Court (ICC) as were many leaders of African countries (Associated Press 2009: 1).

The president of Genocide Watch, Gregory Stanton (2009: 1), wrote on March 23, 2009, an open letter to the United Nations High Commission for Human Rights admiring the action that the ICC took in issuing a warrant for the arrest of President Omar al-Bashir of the Sudan and calling upon them to investigate the crimes Meles and his government had been committing against humanity in the Horn of Africa:

The action that the International Criminal Court has taken in this 
situation has restored hope to peace and justice loving people, affirming that international human rights law not only exists on paper, but in reality. It also sends an important message to perpetrators throughout the world that impunity for their crimes is not assured forever; which may be a primary reason that one of the first leaders to defend Omar al-Bashir and condemn the warrant was Prime Minister Meles Zenawi of Ethiopia, whose government has also been implicated in a pattern of widespread perpetration of serious human rights atrocities in Ethiopia and in Somalia. He and those within his government may be keenly aware of their own vulnerability to similar actions by the ICC in the future that could upend a deeply entrenched system of government-supported impunity that has protected perpetrators from any accountability.

Stanton demonstrates in this letter how the Meles government committed heinous crimes by being involved "in the inciting, the empowerment or the perpetration of crimes against humanity, war crimes and even genocide, often justified by them as 'counter-insurgency.'” He also stated that the Meles government organized Ethiopian National Defense Forces and civilian militia groups to ruthlessly massacre 424 persons from the Annuak people in Gambella on December 2003 in order to suppress opposition and to "exclude them from any involvement in the drilling for oil on their indigenous land.” According to Stanton, as militia groups chanted "Today is the day for killing Annuak," both the military and militias used machetes, axes and guns to kill the unarmed victims, frequently raping the women while chanting, "Now there will be no more Annuak children."

Reports from Amnesty International, the U.S. State Department, and the Human Rights Watch had been continuing to list Zenawi's government extensive record of chilling crimes against the politically and economically oppressed peoples such as the Oromo. The Meles regime passed the socalled anti-terrorism law to legalize its crimes against humanity and to legally intensify its own repressive and terrorist activities. Ethiopia's antiterrorism "law could provide the Ethiopian government with a potent instrument to crack down on political dissent, including peaceful political demonstrations and public criticisms of government policy that are deemed supportive of armed opposition activity” (Human Rights Watch 2009: 1). Generally speaking, the policies and practices of the Ethiopian regime have forced millions of Oromos to become political refugees in Asia, Europe, Australia, and North America. The alliance of the West with this regime has frightened neighboring countries such as Djibouti, Kenya, Sudan, and Yemen, and turned them against the Oromo struggle and Oromo refugees. Using the leverage of Western countries, the regime has pressured neighboring governments to return or expel Oromo refugees from their 
countries. The United Nations High Commission for Refugees (UNHCR) has even failed to provide reasonable protection for thousands of Oromo refugees in Djibouti, Kenya, Sudan, Somalia, and Yemen. For example, on December 21 and 22, 2000, while five thousand Oromo refugees were refouled to Ethiopia, the UNHCR office in Djibouti denied any violation of its mandate had occurred (The Oromia Support Group 2002: 17, 37).

Between 2000 and 2004, hundreds of Oromo refugees were forced to return to Ethiopia from Djibouti to face imprisonment or death (The Oromia Support Group 2003: 16-18). "The continuing refoulement of refugees from Djibouti,” notes the Oromia Support Group (2002: 18-19), “especially the large scale refoulement of December 2000 and the 28 associated deaths by asphyxiation and shooting, should be publicly acknowledged by UNHCR and the Djibouti government." The security agents of Ethiopia and neighboring countries still capture thousands of Oromo refugees and return them to Ethiopia. By crossing borders and entering Somalia and Kenya, agents of the Ethiopian regime assassinated prominent Oromo leaders. And still today, the regime is killing prominent Oromos in Kenya and Somalia. In 2007 and 2008, Ethiopian security forces assassinated Oromos in Somalia and Kenya. One human rights organization notes that on February 5, 2008, the combined security forces of Ethiopia and Puntland, Somalia, bombed two hotels and consequently murdered 65 Oromo refugees and seriously injured more than 100 people. In 2009, the regime killed four Oromos by poisoning their food in Puntland (The Human Right League 2009).

When it comes to the Oromo, international organizations do not pay attention even if terrorist attacks occur and international laws are broken. The Oromo are being denied sanctuary in neighboring countries and are also even being denied the right to be refugees to some degree. Since some Oromo refugees are not welcomed by neighboring countries and international organizations, there are thousands of 'internal' Oromo refugees in Oromia and Ethiopia. Fleeing from Ethiopian state terrorism, these internal refugees hide in the bushes and remote villages. Suspecting that these internal refugees support the Oromo national struggle, the regime attempts to control their movements and the movement of other Oromos. When the regime has been mobilizing the West and the global system by using their resources to terrorize and control the Oromo, the revolutionary nationalist Oromo elites have failed to consolidate the Oromo national struggle because of their ideological confusion and political fragmentation.

As we shall see below, due to the lack of coherent, pragmatic, and strong political leadership, the Oromo national movement faces challenges from the unstable authoritarian-terrorist Ethiopian regime. Moreover, the Oromo national struggle has created political and economic opportunities for those reactionary and opportunist Oromos who promote their personal and 
group interests by allying with and working for the Tigrayan-led Ethiopian government at the cost of the Oromo nation. The sad thing is that this government dispossesses Oromian economic and natural resources to pay for the Oromo collaborators it organized and leads as the OPDO to do its dirty job in Oromia. Had the Oromo national struggle built itself as a more unified, structured, and strong movement, the umbilical cord that links Oromo society to its enemy could have been cut. Today the Oromo collaborators that are in the OPDO mainly maintain such links. Until these "social cancers" exist in Oromo society, it cannot be imagined to liberate Oromia from Ethiopian settler colonialism. These dangerous social elements survive in Oromo society because of the failure of the revolutionary nationalist Oromo elites in establishing a more unified and structured organization and leadership that can mobilize most of the Oromo people to defend their interests. At the same time, the fire of national Oromummaa (Oromo nationalism) survives and expands because of the few selfless and determined Oromo nationalists. However, such nationalist leaders need to expand their mental horizons to re-map and reinvent the Oromo national movement by providing a centralized structured organization and leadership by mobilizing all organizational, cultural, and material resources of the Oromo for national survival and self-defense. Furthermore, the Oromo nationalist elites must maintain their strengths and overcome their weaknesses to mobilize the Oromo for social emancipation, national liberation, self-determination, social justice, and multinational democracy. Without achieving all these objectives, the human rights of the Oromo and other peoples cannot be protected.

\section{The Major Opportunities and Constraints for the Oromo Struggle}

The Oromo national movement that emerged in the 1960s and 1970s by a few determined nationalists reached the Oromo populace in the early 1990s. It took many decades and heavy sacrifices in the lives and sufferings of these few nationalists to resurrect the Oromo name, language, nationhood, and the name of Oromia from the dustbin of history. In this process, national Oromummma has been resurrected. Ethiopian colonialism had disconnected the Oromo from one another and from the international community for more than a century. However, with the resurrection of the Oromo national identity, culture, and nationalism, the Oromo people have started to be represented in the world by its political refugees. For the first time in Oromo history, the Oromo people started to have its Diaspora communities that have a great potential to link Oromia to the global community. The imposition of Ethiopian state terrorism on the Oromo to suppress Oromo nationalism and identity has created and expanded the Oromo Diaspora communities in the world (Jalata 2002). Consequently, a few serious Oromo intellectuals and 
friends of the Oromo emerged on the global level and started to dig the graveyards of history to uncover Oromo history and culture and to publish books and academic articles that are being stored in world libraries.

Furthermore, in Oromia, starting in 1991, when the OLF joined the Transitional Government of Ethiopia for almost a year, millions of the qubee generation (Oromo youth educated in the Oromo language) emerged as demonstrated by the recent Oromo student protest movement. The national projects that were designed by the OLF produced fundamental results that have become the cornerstones of the Oromo national struggle. These achievements are great political opportunities for the Oromo nation. Unfortunately, since the Oromo national struggle did not yet achieve its main objectives of reestablishing a democratic Oromia state by itself or in a multinational context, the enemies of the Oromo people have created political constraints to abort the struggle. Currently, the Tigrayan-led Ethiopian government that claims that it has allowed cultural autonomy for the Oromo and others opposes particularly the manifestation of basic and other forms of Oromummaa. According to the November 2014 report of Amnesty International entitled "Because I am Oromo," "Expression of Oromo culture and heritage have been interpreted as manifestations of dissent, and the government has also shown signs of fearing cultural expression as a potential catalyst for opposition to the government. Oromo singers, writers and poets have been arrested for allegedly criticizing the government and/or inciting people through their work. People wearing traditional Oromo clothing have been arrested at Oromo traditional festivals." 19

There are also millions of Oromos who have betrayed their nation to satisfy their personal and economic interests. By creating and building the OPDO and recruiting such Oromos to this subservient organization, the Tigrayan-led Ethiopian regime uses them to attack the Macha-Tulama SelfHelp Association and the OLF and to suppress and control the Oromo people with the assistance from global powers. The regime has also mobilized several ethnonations against the Oromo people and their movement. There are also anti-Oromo forces such as Amhara colonial organizations and others who use any opportunity to undermine the interest of the Oromo nation. The constraints of the Oromo struggle are not limited to these problems. The Oromo national movement did not yet secure adequate sympathy and support for the Oromo national cause from the international community. It is very clear that the Tigrayan-led government with the support of global powers and its agents terrorizes and rules the Oromo not because of its strengths but

\footnotetext{
${ }^{19}$ Amnesty International, “Because I am Oromo: Sweeping Repression in the Oromia Region of Ethiopia,” November 2014, p. 8.
} 
because of the weaknesses of the Oromo movement, political leadership, and Oromo society. If some elements of Oromo society are well organized under one structured organization and leadership, they can rebel and dismantle the Tigrayan-led Ethiopian regime within a short period. The Tigrayan soldiers, cadres, and their agents can be easily dismantled in Oromia if substantial numbers of Oromos engage in self-defense and coordinated uprisings. If the Oromo people intensify their national struggle, the international community will recognize the political problem of the Oromo nation. The Oromo people will achieve their national self-determination by intensifying their national struggle and by receiving international recognition.

Starting on November 12, 2015, the condition of the Oromo struggle has been transformed by the Oromia-wide peaceful protest movement. The current Oromo protest movement, that is led by Oromo school children and supported by their parents and relatives, demonstrates the maturation of national Oromummaa by overcoming the ideological problem of the Oromo movement. Triggered by the so-called Addis Ababa Master Plan, peaceful protesters all over Oromia are facing the military and the police of the Tigray government, which killed about two hundred people, most of them students. The Tigrayan forces have captured and sent thousands of people to prisons and hidden concentrations camps where they are tortured and girls and women are raped. Despite all these dangers and problems, this protest movement has created a new chapter in the Oromo national movement. Because of this ongoing protest movement, the Oromo national unity and solidarity has been cemented in Oromia and on global level and the international community has started to recognize the struggle of the Oromo people. Young Oromos, without fear of death, are articulating that we will liberate ourselves from Ethiopian colonialism and Tigrayan ethnocracy and dictatorship.

\section{Discussion and Conclusion}

The crisis of the Ethiopian Empire that started in the early 1970s still continues. The popular uprisings of ethnonations, classes, and social groups have challenged the collapsing Ethiopian state for several decades and introduced some changes. These uprisings have resulted in the overthrowing of the Haile Selassie government in 1974 and Mengistu regimes in 1991 and facilitated the emergence of the Tigrayan-led Ethiopian government and Tigrayan ethnocracy. But these changes failed to transform the nature and essence of the Ethiopian colonial state. Ethiopia is still ruled by an authoritarian-terrorist government that practices colonial terrorism and clandestine genocide on the colonized peoples such as the Oromo, Somali, Sidama, Annuak and others. The Tigrayan-led regime has intensified the crisis of the Ethiopian state. 
We know that the Oromo nation lost its political opportunities in the 1970s and again in the 1990s and remained politically insignificant force despite its numerical significance. Learning from the past experiences of the Ethiopian state, we can understand that the Tigrayan-led Ethiopian regime has already dug its own grave. The sudden death of Meles Zenawi who led Ethiopia for twenty-one years with an iron fist on August 20, 2012 has opened a big crack in the Tigrayn-led Ethiopian government. The Tigrayanled regime is already rotten from inside, and it only survives because of the weaknesses of different political forces in the empire and the financial, military, and diplomatic support it receives form powerful countries. Are the OLF and other Oromo political organizations ready to use the emerging political crisis? Oromo nationalists, liberation fronts, political organizations, community organizations and associations should start a serious national political dialogue to overcome their political naiveté and immaturity in order to build a national political consensus that will enable them to capture state power in Oromia and to build a multinational democracy with other nations that accept the principles of self-determination and democracy. While preparing themselves to use any available political opportunity, the Oromo national movement and society must start to fashion a national Gumii Gayyo (multitudes of legislative national assembly) to produce designed political results.

These designed political results can be produced through determination, hard work, sacrifice, and a collective effort of all Oromo liberation fronts, political organizations, and civic associations. History demonstrates that determined peoples can determine their political destinies by liberating themselves. The Oromo elites in general and that of the Diaspora in particular must start to determine the destiny of their nation by taking the following concrete steps immediately. First, in the Diaspora, they must initiate town hall meetings in every town wherever the Oromo community live and discuss about the fate of the Oromo people by focusing on their achievements, failures, challenges, and constraints as a nation. In the Ethiopian Empire, the Oromo people are denied the freedom of selfexpression, organization, and the media. So most of the open discussions must take place in the Diaspora. Oromo activists and organizations in Oromia need also to intensify their discussions and struggle clandestinely.

Second, the Oromo in the Diaspora must stop the politics of selfdestruction by avoiding engaging in clan, religious, and regional politics, and by isolating the Oromo mercenaries from every Oromo community. Since the Oromo mercenaries use clan, religious, and regional politics to divide the Oromo people and turn them against one another, the Oromo community must reject them and their politics.

Third, the Oromo Diaspora must challenge the Oromo activists who 
have built their separate organizations in order to break down barriers among different Oromo organizations and unite them under one structured organization and leadership. Fourth, Oromo youth and women should be mobilized in order to actively participate in national dialogues and town hall meetings; they must play a leading role since they are less corrupted by the ideologies of egoism, clanism, religious and regional politics. Fifth, Oromo nationalists must establish the rule of law to fashion their frameworks on the principles of gadaa and other democratic traditions in order to use them in running their national affairs. Sixth, since unconscious people cannot liberate themselves from colonial and other forms of domination, the Oromo Diaspora should receive liberation knowledge through regular dialogues, seminars, conferences, workshops, lectures, and study circles. The Oromo must learn their history, culture, language, and traditions; they also need to learn about the world around them. At this historical moment, the number one enemy of the Oromo people is political ignorance; Oromo nationalists must smash this enemy. When this is accomplished, the Oromo people are going to play their historical role that will commensurate with their number. When this sleeping giant nation will be awakened, others cannot use the Oromo as raw materials.

One of the main reasons why about forty million Oromos are terrorized and ruled by the elites that emerged from about five million Tigrayans is the lack of political consciousness. Seventh, every self-respecting Oromo must realize that he or she has power to determine the destiny of Oromia. Every Oromo must be educated about his or her potential power and what he or she must do to translate it to real power. Eighth, the Oromo Diaspora movement must start building from bottom-up a confederation of Oromo political, religious, community, and self-help organizations to create a Global Gumii Oromia that will contribute ideological, organizational, and financial resources for consolidating the Oromo struggle and the Oromo Liberation Army and self-defense militias in Oromia. This global structure will also help in developing global Oromummaa based on the principles of social justice, mutual solidarity, egalitarian democracy, and human liberation from all forms of exploitation and injustices on the global level. Ninth, all members of the Oromo Diaspora must engage in public diplomacy by introducing the Oromo and their plight to the international community. Tenth, Oromo nationalists in the Diaspora must start to build a well-regulated system that can provide support and security for Oromos who are determined to advance the Oromo national interest whenever they face hardship beyond their control. Finally, the Oromo must believe that they will liberate themselves if they are committed, work hard, and be ready to pay the necessary sacrifice. The Oromo people should recognize that they are the only one who can advance and protect their human rights; it is only then that 
international organizations respect them and start to protect their fundamental human rights. Until the Oromo take care of their business, international laws and covenants will remain on paper without solving the gross human rights violations of the Oromo people.

Finally, the ongoing Oromo protest movement not only needs to build its organizational capacity, but also needs to develop strategic visions and political plans for working with other peoples who are interested to implement the principles of self-determination and egalitarian multinational democracy. While Oromo activists engage in debates and dialogues for formulating policies that reflect their indigenous democracy, they must also develop political plans that they can share with other peoples who have similar interests for discussion, debate and consensus building. The Oromo people can play a central role in implementing the principles of selfdetermination and multinational democracy provided that it will effectively mobilize their abundant human and economic resources, and ally with others to build their human capabilities. In developing leadership and organizational capacity, emphasize should be given to build organizations and institutions rather than promoting the egos and leadership of individuals to avoid the pitfalls of liberation movements that won liberation wars, but failed to build healthy and effective democratic societies. The disaster of Tigrayan liberation movement is a living example. This movement only won the war against the Ethiopian state and eventually became its photocopy after capturing state power. Recently, the Tirayan-led regime has excelled its predecessor by committing more crimes against humanity. All colonized subjects, including the Amhara people, must ally with the Oromo protest movement based on the principles of national self- and mutual-interest, selfdetermination, and multinational democracy to dismantle this terrorist regime.

Developing a united, skillful, knowledgeable and determined leadership that believes truly in democratic principles and hard work is very crucial for the advancement and success of the Oromo and other movements in Ethiopia today. For Oromo society, building the kind of leadership and organization that reflect the Oromo democratic and consultative traditions is absolutely necessary to fully develop the Oromo organizational capacity. The same is true for the other societies. Those Oromo leaders, who created the Macha-Tulama Self-Help Association and the Oromo Liberation Front, reflected some Oromo democratic and consultative traditions although such traditions were gradually undermined with external pressures and internal crises in the Oromo movement. If the colonized societies, such as the Oromo, cannot develop skills, knowledge and capabilities to promote and exercise freedom and egalitarian democracy while engaging in protest and liberation struggles, they may inadvertently replace colonial dictatorships by 
national or other forms dictatorships. Therefore, the Oromo liberation movement and other movements must start to practice freedom and egalitarian democracy while struggling to overthrow Tgrayan colonial dictatorship.

\section{References:}

Amnesty International, Human Rights Watch/Africa. 1991-2007. Series. Associate Press, 2009.

Balibar, Etienne and Immanuel Wallerstein 1991. Race, Nation, Class: Ambiguous Identities. 'New York: Verso.

Barker, Colin. 2001. "Robert Michels and the 'Cruel Game,'” Leadership and Social Movements. Manchester: Manchester University Press.

Barta, Tony. 2007. "On Pain of Extinction: Laws of Nature and History in Darwin, Marx, and Arendt." Hannah Arendt and the Uses of History: Imperialism, Nation, Race and Genocide. Edited by Richard H. King and Dan Ston. New York: Berghhn Books, PP. 87-108.

Berberoglu, Berch. 2003. Globalization of Capital and the Nation-State. Lanham, Maryland: Rowman \& Littlefield Publishers, Inc.

Bulatovich, Alexander. 2000. Ethiopia through Russian Eyes: Country in Transition. Translated by Richard Seltzer. Lawrenceville, NJ: The Red Sea Press.

Chalk, Frank and Kurt Jonassoh. 1990. History and Sociology of Genocide: Analyses and Case Studies. New Heaven, Conn.: Yale University Press. de Salviac, Martial. 2005[1901. An Ancient People, Great African Nation. Translated by Ayalew Kano. East Lansing: Michigan.

Fossati, Bruna,L.Namarra,andPeterNiggli. 1996. The New Rulers of Ethiopia and the Persecution of the Oromo: Reports from the Oromo Refugees in Djibouti. Dokumentation, Evangelischer Pressedienst Frankfurt am. Giorgis, Tamrat G. 2009. “A Stranger Comes to Town.” Addis Fortune. Vol. 10 , no. 486. http://www.addisfortune.com/Vol\%2010\%20No\%20486\%20Archive/agenda. htm.

Harvey, David. 2005. A Brief History of Neoliberalism. Oxford: Oxford University Press.

Hasselblatt, Gunnar. 1992. "After Fourteen Years: Return to Addis Ababaand to a Free Oromia,” December 1991-January 1992,” A Travel Diary, Berlin.

Hassen, Mohammed. 2001. "Is Genocide Against the Oromo in Ethiopia Possible,” Paper Presented at the Fourth International Biennial Conference of the Association of Genocide Scholars, Radisson Hotel, Minneapolis, Minnesota, June 10.

Hassen, Mohammed. 2002. “Conquest, Tyranny, and Ethnocide against the 
Oromo.” Northeast African Studies, vol. 9, no. 3.

Herman, E. S. 1982. The Real Terror Network: Terrorism in Fact and Propaganda. Boston: South End Press.

Hizbawi Adera. 1996, 1997. A TPLF/EPRDF (government) Political Pamphlet, Dec.1996-Feb. 1997, Vol. 4. No. 7.

Herbert, Edwin. 2003. Small Wars and Skirmishes 1902-18. Nottingham, Great Britain: Foundry Books.

Hoffman, Bruce. 2006[1998]. Inside Terrorism, (New York: Columbia University.

Hochschild, Adam. 1998. King Leopold's Ghost: A Story of Greed, Terror, and Heroism in Colonial Africa. New York: Houghton Mifflin Company. Holcomb, Bonnie and Sisai Ibssa. 1990. The Invention of Ethiopia. Trenton: The Red Sea Press.

Human Rights Watch. 2005. Human Rights,” Website: www.genocidewatch.org, accessed on April.

Human Rights Watch. 2005. May, vol. 17, no. 7 (A).

Human Rights League of the Horn of Africa. 2008, 2009. "Refugees Poisoned to Death in Puntland, Somalia," December 19, 2009. http://www.humanrightsleague.com/press_Releases.html

Human Rights Watch. 2009. "An Analysis of Ethiopia's Draft Anti-Terrorism Law,” updated June 30.

Jalata, Asafa. 2005[1993]. Oromia \& Ethiopia. Lawrenceville, NJ: The Red Sea Press.

Jalata, Asafa. 2012[2001]. Fighting Against the In justice of the State and Globalization: Comparing the African American and Oromo Movements. New York: Palagrve Macmillan.

Jalata, Asafa. 1998. Oromo Nationalism and the Ethiopian Discourse: The Search for Freedom and Democracy, edited, (Lawrenceville: The Red Sea Press).

Jalata, Asafa. 2007. Oromummaa: Oromo Culture, Identity and Nationalism. Atlanta: Oromia Publishing Company.

Jalata, Asafa. 2010. Contending Nationalisms of Oromia and Ethiopia: Struggling for Statehood, Sovereignty, and Multinational Democracy. Binghamton, NY: Global Academic Publishing.

Jalata, Asafa. 2011. "Terrorism from Above and Below in the Age of Globalization,” Sociology Mind, Vol. No. 1: 1-16.

Jalata, Asafa. 2005. "State Terrorism and Globalization: The Cases of Ethiopia and Sudan,” International Journal of Comparative Sociology, Vol. 46(1-2): 79-102.

Jalata, Asafa. 2002. "The of the Oromo Diaspora in the Oromo National Movement: Lessons from the Agency of the 'Old' African Diaspora in the United States,” Northeast African Studies, Vol. 9., No. 3: 133-160. 
Jonassohn, Kurt. 1998. Genocide and Gross Human Rights Violations: In Comparative Perspective. New Brunswick: Transaction Publishers. Johnson, Alan. 2001. "Self-emancipation and Leadership: The Case of Martin Luther King.” Leadership and Social Movements. Edited by Colin Barker, Alan Johnson and Michael Lavalette. Manchester: Manchester University Press.

Kiernan, Ben. 2007. Blood and Soil: A World History of Genocide and Extermination from Sparta to Darfur. New Heaven: Yale University Press.

King, Richard and Dan Stone, (eds.) 2007. Hannah Arendt and the Uses of History. New York.Berghahn Books.

Largesse, Amarom. 2006 [2000]. Oromo Democracy. Lawrenceville: Red Sea Press.

Legesse, Asmarom. 1973. Gada: Three Approaches to the Study of African Soceity. New York: Free Press.

Lord, Robert G. and Douglas Brown. 2004. Leadership Processes and Followers Self- Identity. Mahwal, NJ: Lawrence Erlbaum Associate, Inc.: 2004.

MacKinnon, Catharine. 1994. "Rape, Genocide, and Women’s Human Rights," Harvard Women's Law, Journal 17.

Malik, Kenan. 1996. The Meaning of Race. New York: New York University Press.

Marx, Karl. 1967. Capital. F. Engels (Ed.). New York: International Publishers.

The Oromia Support Group. 1997; 2002; 2003 series.

The Oromia Support Group. 1997 series.

The Oromo Relief Association, 1980.

The Human Rights League of the Horn of Africa. 2009.

Oliverio, Annamarie. 1997. "The State of Injustice: the Politics of Terrorism and the Production of Order.” International Journal of Comparative Sociology, Vol. 38.

Pollock, Sue. 1996. "Ethiopia-Human Tragedy in the Making: Democracy or Dictatorship?" The Oromia Support Group.

Pollock, Sue. 1997. "Politics and Conflict: Participation and Selfdetermination." Ethiopia: Conquest and the Quest for Freedom and Democracy. Edited by Seyoum Y. Hameso, T. Trueman, and T. E. Erena. London: TSC Publications, 1997, pp. 81-110.

Rahmato, Dessalegn. 2011. "Land to Investors: Large-Scale Land Transfers in Ethiopia.

www.ethioobserver.net/Ethiopia_Rahmato_FSS_0.pdf.

Robinson, William I. 2008. Latin America and Global Capitalism. Baltimore: John Hopkins University Press. 
Rodney, Walter. 1972. How Europe Underdeveloped Africa. Washington, D.C.: Howard University Press.

Singer, Norman J. 1978. “Ethiopia: Human Rights, 1948-1978,” Proceeding of the First International Conference on Ethiopian Studies. April 1316, pp. 672-673.

Sturgis, Amy H. 2007. The Trail of Tears and Indian Removal. Westport, CT: Greenwood.

Stanton, George. 2009. "An Open Letter to the United Nations High Commissioner for Human Rights,” Website: www.genocidewatch.org, accessed on April 1, 2009.

Survival International, 1995.

Trueman, Trevor. 1997. "Democracy or dictatorship." Ethiopia: Conquest and the Quest for Freedom and Democracy, edited by Seyoum Y. Hameso, T. Trueman, and T. E. Erena, London: TSC Publications, 1997), in Ethiopia, ibid, pp. 141-150.

Trueman, Trevor. 2001. "Genocide against the Oromo People of Ethiopia? Western Influence," Paper Presented at the 44th Annual Meeting of the African Studies Association, Houston, Texas, November 14-18.

Waltzer, Michael. 1977. Just and Unjust Wars: A Moral Argument with Historical Illustrations. New York: Basic Books.

Winant, Howard. 1994. Racial Conditions: Politics, Theory, Comparisons. Minneapolis: University of Minnesota.

Worku, Kenate. 2009. "The Expansion of Addis Ababa and its Impact on the Surrounding Areas: A Preliminary Study of the Nefas Silk Lafto District," The Journal of Oromo Studies, Vol. 15, No. 2, July, pp. 97-131.

Wolfe, Patrick. 1998. Settler Colonialism and the Transformation of Anthropology. London: Cassel. 